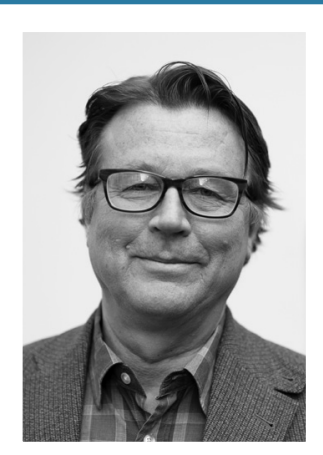

\title{
PÄ̈̈KIRJOITUS
}

\section{KAMPPAILU AIKUISTEN KASVATUKSESTA}

A

IKUISKASVATUKSEN JA -KOULUTUKSEN historiaa on monissa yhteyksissä tavattu idealisoida lähtökohtana aikuisen ihmisen tarve sivistää itseään. On puhuttu tiedonnälästä ja tiedonjanon sammuttamisesta. Tämän kertomuksen päähenkilö on nuoruusiällä jäänyt vähäisen koulutuksen varaan, mutta saanut sittemmin aikuisena jonkin ristiriitaisen kokemuksen tai omakohtaisesti koetun tiedonpuutteen vuoksi sivistysherätyksen. Hän onnistuu yksilöllisen sitkeyden ja päättäväisyyden ansiosta nousemaan yhteiskuntaluokkansa ankeista oloista kultivoituneempaan elämään omaksumalla keskiluokalle ominaisia ajattelu- ja elämäntapoja. Tiedonjanon tyydyttäminen tulee palkituksi sosiaalisella nousulla.

Ylevöittävä kertomus on tietenkin myytti. Aikuiset eivät menneinäkään vuosikymmeninä joukkomitassa antautuneet sivistysopintoihin. Omaehtoisen opiskelun avulla sosiaalista nousua vauhdittaneet olivat poikkeustapauksia. Kertomus on myytti toisessakin merkityksessä. Kansalaisten omaehtoiset sivistyspyrinnöt ovat olleet marginaalissa suhteessa siihen ylhäältäpäin organisoituun kasvatustoimintaan, jossa aikuiset nähtiin pikemmin kohteina kuin subjekteina. Kansansivistystyö oli keino saattaa kansan omat pyrinnöt hallittaviin uomiin.

Sittemmin 1900-luvun mittaan sivistystyö sai antaa tilaa tärkeämmäksi koetulle ammatilliselle aikuiskoulutukselle. Kun sivistystyötä olivat järjestäneet kuntien lisäksi lukuisat järjestöt, ammatillisesta aikuiskoulutuksesta huolehti henkilöstökoulutusta lukuun ottamatta julkinen valta. Nyt 2000-luvulla talouskasvua tukeva ja työelämän tarpeita palveleva ammatillinen aikuiskoulutus on valtiovallan ykkösprioriteetti aikuiskoulutuspolitiikassa. Ylipäätään talouden argumentit ovat aiempaa vahvemmin kaiken koulutuspolitiikan ytimessä, kunnallisesta päivähoidosta yliopistoihin.

AIKUISKASVATUKSEN JA -KOULUTUKSEN perinteiset instituutiot ovat tätä nykyä vain yksi toimija sillä kentällä, jolla määritellään, millainen aikuisen kansalaisen tulisi olla. Ja kun aiemmin aikuisen malli oli enimmäkseen kotoperäinen perustuen vahvasti kansallisiin ihanteisiin ja kansallisvaltion tarpeisiin, nykyään Euroopan unionin ja OECD-talousjärjestön kaltaiset ylikansalliset organisaatiot laativat yhä yksityiskohtaisempia kuvauksia kaikkien teollisuusmaiden aikuisväestöltä vaadittavista tiedoista, taidoista ja asenteista.

Niin EU kuin OECD ovat laatineet kuvauksia kaikille kunnon kansalaisille kuuluvista avaintaidoista. Jäsenvaltiot ottavat vaatimukset avaintaidoista kilpailukyvyn turvaamisen hengessä ohjeistukseksi kansallisesti toteutettavaan aikuiskoulutuspolitiikkaan. Näin sekä EU että OECD pyrkivät perimmältään lisäämään talouksien kilpailukykyä ja kiihdyttämään talouskasvua. 


\section{Miten AIKUISKOULUTUS VOISI VASTATA}

TARPEESEEN PITÄÄ PLANEETTA ELINKELPOISENA?

Vahvojen ylikansallisten organisaatioiden ohella erittäin vahva vaikuttaja on media monissa muodoissaan. Se on täynnä aikuisille suunnattuja viestejä siitä, millaisia heidän tulisi olla ja miten elää. Teollisuus markkinointikoneistoineen toimii samoilla markkinoilla perinteisempien aikuiskasvattajien kanssa. Molemmat tahot pyrkivät muokkaamaan aikuisten ajattelua ja toimintaa.

Tieteeseen ja tutkimukseen perustuvien opetusten auktoriteettiasema ei enää ole itsestään selvä. Se on saanut haastajakseen epätieteellisiä tulkintoja monimutkaisista yhteiskunnallista ja ekologisista ilmiöistä. Eivätkä asialla ole vain taloudellisia etujaan ajavat toimijat. Mukaan on lähtenyt eri maissa poliittisen järjestelmän avaintehtävissä toimivia päätöksentekijöitä ja lainsäätäjiä. Heitä on myös Suomessa.

ISO OSA AIKUISKOULUTUSTUTKIMUKSISTA ja alan erilaisista selvityksistä kohdistuu työelämän ja aikuiskoulutuksen vastaavuuteen. Päällimmäinen huoli on, miten hyvin koulutus tai kurssi vastaa työelämän tarpeita. $\mathrm{Ne}$ otetaan paljolti annettuina: 'työelämän tarpeet' ovat sitä, mitä työnantajat määrittävät työelämän tarpeiksi.

Kun maailmaa katsotaan uusimman tieteellisen tutkimuksen valossa, tärkeimpänä ongelmana tuskin voidaan pitää liian vähäistä talouskasvua. Ongelma on pikemmin se, miten talouskasvu on saatu aikaan. Sitä on synnytetty luonnon ja koko maapallon kestokyvystä piittaamatta. Tässä Aikuiskasvatuksen teemanumerossa koetetaan hahmottaa, miten aikuiskoulutus voi vastata tarpeeseen pitää planeetta elinkelpoisena ihmiselle ja muille lajeille.
OPETUKSIA EKOLOGISEMMASTA YHTEISK UNNASTA ja tuhlaamista välttävästä taloudesta ei oteta kaikkialla avosylin vastaan. Lihantuottajat eivät riemuitse siitä, että ihmiset siirtyvät eläinproteiinista kasviproteiinin käyttöön, vaikka se onkin ekologisesti perusteltua. Asenteita ja kulutustottumuksia pyritään muokkaamaan markkinoimalla lihaa mielikuvilla eläinten hyvinvointia kunnioittavasta tuotannosta. Se vain ei muuta miksikään sitä tosiasiaa, että ekologisesti järkevämpää olisi käyttää karjan kasvattamiseen tuotettava kasviproteiini ihmisen ravinnoksi.

Kulutustottumukset ovat talouden tarpeiden ja ihmisten tarpeiden risteyskohta. Esimerkistä käy jakamistaloudesta tuttu malli asuntojen lyhytaikaisesta vuokraamisesta. Tunnetuimpia toimijoita on Airbnb, jota vastaan hotelliyritykset ovat voimakkaasti hyökänneet monenlaisin argumentein. Argumenteissa kiteytyy hyvin laajemminkin yksi talousjärjestelmän ja ihmisten tarpeiden ristiriita: hotelliyritysten perimmäinen tarkoitus ei ole majoituksen järjestäminen sinänsä vaan bisneksen tekeminen ihmisten majoitustarpeella.

Vakiintuneiden taloudellisten intressien puolustaminen on tärkein este nykyistä ekologisemmille elämänmuodoille. Kehittyneet taloudet ovat täynnä infrastruktuuria, esimerkiksi rakennuksia, autoja, työvälineitä, jota jakamalla ei-niin-välttämätöntä kuluttamista voitaisiin radikaalisti vähentää. Ongelma vain on siinä, että se loukkaisi taloudellis-teollisen kompleksin intressejä.

Heikki Silvennoinen 